\title{
GANADO MENOR Y ENFOQUE DE GÉNERO. APORTES TEÓRICOS Y METODOLÓGICOS
}

\author{
MINOR LIVESTOCK AND GENDER APPROACH: THEORETICAL AND \\ METHODOLOGICAL CONTRIBUTIONS
}

\author{
Verónica Vázquez-García \\ Desarrollo Rural, Colegio de Postgraduados, Carretera Federal México-Texcoco Km. 36.5, \\ Montecillo, Estado de México. 56230 (vvazquez@colpos.mx)
}

\begin{abstract}
RESUMEN
La presencia de ovinos y caprinos en México es marginal, en comparación con otras partes del mundo. También es reducido su consumo en relación con la carne de res. Sin embargo, ambas especies son importantes para la tradición culinaria mexicana y para la economía campesina. Este artículo persigue dos objetivos: analizar las relaciones de trabajo en sistemas de producción ovina y caprina en México; y proponer nuevos acercamientos teórico-metodológicos para la investigación y el diseño de políticas públicas dirigidas al sector. En él se argumenta que el análisis de género de los sistemas productivos de ganadería menor permite comprender y documentar de manera más efectiva el trabajo de mujeres y hombres en la producción animal, así como las desigualdades de género en el acceso y control sobre tierras de pastoreo, insumos, servicios veterinarios y crediticios.
\end{abstract}

Palabras clave: acceso, control, división genérica del trabajo, pequeños rumiantes, sistemas productivos.

\section{INTRODUCCIÓN}

$\mathrm{L}$ as mujeres rurales juegan un importante papel en la producción animal del mundo entero, en particular de aves, porcinos y pequeños rumiantes. Estos animales tienen la ventaja de que pueden criarse a bajo costo (cerca de la vivienda o en tierras de propiedad común) y proporcionan múltiples beneficios (alimento, fertilizante, tracción, ingresos, ahorro) (Peacock, 2005). Además de cuidarlos y alimentarlos, las mujeres participan en la elaboración y venta de productos derivados de la producción animal, por ejemplo lácteos y artesanías de piel y lana.

* Autor responsable * Author for correspondence.

Recibido: junio, 2014. Aprobado: junio, 2015.

Publicado como ARTÍCULO en ASyD 12: 515-531. 2015.

\section{Abstract}

The presence of sheep and goats in Mexico is marginal, compared to other parts of the world. Their consumption is also reduced compared to beef's. However, both species are important for the Mexican culinary tradition and for peasant economy. This article pursues two objectives: analyzing the work relationships in sheep and goat production systems in Mexico; and suggesting new theoretical-methodological approaches for research and public policy design for the sector. It argues that gender analysis of minor livestock productive systems allows understanding and effectively documenting the work of women and men in animal production, as well as gender inequalities in the access and control of grazing lands, inputs, veterinary services and credit.

Keywords: access, control, gender division of labor, small ruminants, productive systems.

\section{INTRODUCTION}

$\mathrm{R}$ ural women play an important role in animal production throughout the world, particularly of poultry, pigs and small ruminants. These animals have the advantage that they can be bred at low cost (near the household or in common property lands), and they provide multiple benefits (food, fertilizer, traction, income, savings) (Peacock, 2005). In addition to taking care of them and feeding them, women participate in the elaboration and sale of products derived from animal production, for example dairy and leather and wool handcrafts. This does not mean, however, that they are formally the animal owners, or that they can benefit directly from their processing and sales. In general, women face difficulties of access and control of grazing lands, water, fodder, credit, veterinary services, markets and other essential resources for 
Esto no quiere decir, sin embargo, que formalmente sean las dueñas de los animales, o que se beneficien directamente de su procesamiento y venta. En general, las mujeres enfrentan dificultades de acceso y control sobre tierras de pastoreo, agua, forraje, crédito, servicios veterinarios, mercados y otros recursos esenciales para la producción, situación que dificulta sus labores (Eade y Williams, 1995; Budak et al., 2005; World Bank, 2009; FAO, 2012).

El ganado menor forma parte de muchos paquetes tecnológicos de apoyo al campo debido a su reconocida capacidad de fortalecer la seguridad alimentaria (Martínez-González et al., 2013). Sin embargo, las relaciones de género en torno a su producción no han sido adecuadamente estudiadas ni comprendidas en el diseño de política pública. En ocasiones las mujeres son quienes manejan los rebaños, pero no son reconocidas como tales por las personas que promueven los paquetes. Diversos estudios Todd, 1998; Flintan, 2008; Pollot y Wilson, 2009; Taj et al., 2012; FAO, 2012) han demostrado que los programas que integran cuestiones de género (información desagregada por sexo, investigación previa sobre las estructuras familiares y comunitarias que rigen el acceso a los recursos, extensionismo sensible al género) obtienen resultados positivos que benefician no sólo a las mujeres, sino a todo el grupo doméstico.

Este artículo persigue dos objetivos. El primero es analizar las relaciones de trabajo en sistemas de producción ovina y caprina en México, mientras que el segundo es proponer, a partir de este análisis, algunas ideas para hacer visible la participación femenina en la crianza de ganado menor de unidades campesinas. El artículo se compone de cuatro apartados restantes. Los dos primeros ofrecen un panorama de la presencia y utilidad de ovinos y caprinos en el país, mientras que los dos últimos analizan la conceptualización del trabajo y proponen nuevas maneras de hacerlo. Se argumenta que la perspectiva de género permite documentar y analizar el trabajo de hombres y mujeres en la producción animal, así como de la problemática de género en torno al acceso y control sobre tierras, insumos, servicios veterinarios y crediticios. Incorporarla al estudio de la ganadería menor conduce a un mejor diseño de la política pública orientada a fortalecer la seguridad alimentaria en comunidades campesinas de México. production; this situation makes their work difficult (Eade and Williams, 1995; Budak et al., 2005; World Bank, 2009; FAO, 2012).

Minor livestock is part of many technological packages of support to the countryside because of its recognized capacity to strengthen food security (Martínez-González et al., 2013). However, gender relations around its production have not been adequately studied or understood in the design of public policies. Sometimes women are the ones who manage flocks, but they are not recognized as such by the people who promote the packages. Diverse studies (Todd, 1998; Flintan, 2008; Pollot and Wilson, 2009; Taj et al., 2012; FAO, 2012) have shown that the programs that integrate gender issues (information disaggregated by sex, prior research about the family and community structures that rule access to resources, or outreach sensitive to gender) obtain positive results that benefit not only women, but the whole domestic group.

This article pursues two objectives. The first one is to analyze the work relationships in the sheep and goat production systems in México, while the second one is to propose some ideas, based on this analysis, to make the feminine participation in minor livestock breeding of peasant units visible. The article is made up of four remaining sections. The first two offer a panorama of the presence and utility of sheep and goats in the country, while the latter two analyze the conceptualization of work and propose new ways to do it. It is argued that the gender perspective allows documenting and analyzing men and women's work in animal production, as well as the gender problematic around access and control of lands, inputs, veterinary services and credit. Incorporating this perspective into the study of minor livestock leads to better design of the public policy directed at strengthening food security in México's peasant communities.

\section{Presence ANd distribution of SMALL RUMINANTS IN MÉXICO}

Both sheep and goats were introduced to America with the Spanish invasion of 1492 (Nahed-Toral, 2002). Those who are present today in the country are called "Creole" because they are descendants of the ones brought by the Spanish, although new breeds have been introduced in the last 25 years 


\section{Presencia y distribución de PeQueños RUMIANTES EN MÉXICO}

Tanto los ovinos como los caprinos fueron introducidos a América con la invasión española de 1492 (Nahed-Toral, 2002). Los que existen hoy en el territorio nacional son denominados "criollos" por descender de aquellos traídos por los españoles, aunque en los últimos 25 años nuevas razas han sido introducidas (Tovar, 2009). Ovinos y caprinos han sido adaptados a la cultura rural y culinaria de México para la elaboración de platillos tradicionales como la barbacoa (centro del país), cabrito (en el norte) y chivo cebado (en la Mixteca poblana y oaxaqueña).

En los últimos cinco años, México ha presentado un incremento en el inventario de ovinos: de 6’050,000 en 2005 a 8'219,386 cabezas en 2011 (Pérez et al., s.f; SAGARPA, 2011). EL Cuadro 1 muestra que la mitad (49\%) se distribuyen en cinco estados: Estado de México (15.9\%), Hidalgo (13.4 \%), Veracruz (8.1\%), Oaxaca (6.1\%) y Puebla (5.5\%). La presencia de ovinos ha disminuido particularmente en San Luis Potosí y Chiapas (dos estados tradicionalmente fuertes) y aumentado en Veracruz y Sinaloa debido a la introducción de razas australianas en el noroccidente y la expansión del pelibuey en Veracruz (Amendola et al., 2006). La distribución regional tiene mucho que ver con el tipo de animal. En el norte se utilizan razas especializadas en producción de carne, mientras que en el centro predomina la cruza de razas que se alimentan principalmente en agostaderos. Finalmente, en el sur del territorio nacional prevalecen las razas de pelo (Pérez et al., s.f.).

A finales del siglo XIX, los caprinos eran el tercer producto de exportación de México. Entre 1994 y 2004 se presentó una reducción de $10 \%$ en el número de cabezas a nivel nacional, mientras que en el mundo aumentó en 21 \% (Gómez et al., 2012). A lo largo de la década de 2000, la caída en México siguió presentándose (Tovar, 2009). A pesar de ello, el inventario nacional de caprinos es un poco mayor que el de ovinos. SAGARPA (2011) documenta un total de 9'004,377 cabezas, la mitad de las cuales (50\%) están en cinco estados: Puebla (14.9\%), Oaxaca (13.4\%), Guerrero (7.5\%), Coahuila (7.3 \%) y San Luis Potosí (6.8 \%) (Cuadro 1). Los caprinos se han adaptado en las regiones áridas o semi-áridas de estos estados gracias a su habilidad para sobrevivir en
Cuadro 1. Inventario de ovinos y caprinos (2011). Table 1. Inventory of sheep and goats (2011).

\begin{tabular}{lll}
\hline Especie & $\begin{array}{c}\text { Número } \\
\text { de cabezas }\end{array}$ & \multicolumn{1}{c}{$\begin{array}{c}\text { Estados } \\
\text { predominantes }\end{array}$} \\
\hline Ovinos & $8^{\prime} 219,386$ & $\begin{array}{l}\text { Estado de México }(15.9 \%) \\
\text { Hidalgo }(13.4 \%)\end{array}$ \\
& & Veracruz $(8.1 \%)$ \\
& Oaxaca $(6.1 \%)$ \\
& & Puebla $(5.5 \%)$ \\
& & Resto $(51 \%)$ \\
Caprinos & \multirow{2}{*}{004,377} & Puebla $(14.9 \%)$ \\
& & Oaxaca $(13.4 \%)$ \\
& & Guerrero $(7.5 \%)$ \\
& & Coahuila $(7.3 \%)$ \\
& & San Luis Potosí $(6.8 \%)$ \\
& & Resto $(50 \%)$ \\
\hline
\end{tabular}

Fuente: SAGARPA (2011). Source: SAGARPA (2011).

(Tovar, 2009). Sheep and goats have been adapted to the rural and culinary culture of México for the elaboration of traditional dishes like barbacoa (center of the country), cabrito (in the north) and chivo cebado (in Puebla's and Oaxaca's Mixtec region).

In the past five years, México has presented an increase in the inventory of sheep: from 6'050,000 in 2005 to 8'219,386 heads in 2011 (Pérez et al., s.f; SAGARPA, 2011). Table 1 shows that half (49\%) are distributed in five states: Estado de México (15.9\%), Hidalgo (13.4\%), Veracruz (8.1\%), Oaxaca (6.1 \%) and Puebla (5.5\%). The presence of goats has decreased, particularly in San Luis Potosí and Chiapas (two states that were traditionally strong), and increased in Veracruz and Sinaloa due to the introduction of Australian breeds in the northwest and the expansion of Pelibuey in Veracruz (Amendola et al., 2006). The regional distribution has a lot to do with the type of animal. In the north the breeds used are specialized for meat production, while in the center the cross of breeds that feed mainly in pasturelands predominates. Finally, hair breeds prevail in the south of the country (Pérez et al., s.f.).

At the end of the $19^{\text {th }}$ Century, goats were the third export product in México. Between 1994 and 2004 there was a reduction of $10 \%$ in the number of heads at the national level, while globally it increased in $21 \%$ (Gómez et al., 2012). Throughout the 2000s, the fall in México continued (Tovar, 2009). Despite this, the national inventory of goats is slightly larger than sheep's. SAGARPA (2011) documents a 
situaciones de escasez y al manejo extensivo que se le da a los rebaños (Nagel et al., 2006; Escareño et al., 2012).

El número de ovinos y caprinos que existen en México es bajo, en comparación con otros lugares del mundo. Datos de la FAO (en Pérez et al., s.f.:3) indican que la población mundial de ovinos en 1999 era de 1,083 millones de cabezas, distribuidas en Asia (38.3\%), África (19.7\%), Oceanía (15.8\% ), Europa (15\%), Sudamérica $(9.7 \%)$, y Norte y Centro América (1.5\%). Sobre las cabras, Escareño et al. (2012) señalan que existen 617 millones, con mayores proporciones en Asia (66\%) y África $(27.4 \%)$ y menores en Europa (3.5\%) y América (3\%).

\section{Principales PROductos: CARne, lana de BORREGO Y LECHE DE CABRA}

México ocupa el lugar 17 en la producción de carne a nivel mundial (Escareño et al., 2012). Sin embargo, en el sector de rumiantes, la de res concentra aproximadamente $95 \%$ del valor del mercado. El consumo de carne ovina equivalía al $1 \%$ del total en 2001, con 1.0 kilogramos de consumo per cápita, en comparación con 16.5 kilogramos de carne de res. Para 2005, la cantidad sólo había subido a 1.3 kilogramos anuales por persona, y en 2011 su consumo fue de $0.95 \%$ (Pérez, s.f.; Morales et al., 2004; Améndola et al., 2006; Arteaga, 2012). Con la carne de caprinos sucede algo similar, ya que representa $0.85 \%$ del mercado nacional (Gómez y Echavarría, 2006).

Otros productos obtenidos de pequeños rumiantes son la lana de borrego y la leche de cabra. La primera tiene presencia en cuatro estados con tradición artesanal textil (Hidalgo, México, Zacatecas y Tlaxcala), pero se encuentra en declive debido al aumento en el uso de fibras sintéticas. En 2008 se producían 4518 toneladas de lana, con una caída de $31 \%$ respecto a 1980 . En 2011, la producción se quedó prácticamente igual (4696 toneladas). La lana tiene un precio muy poco redituable (3.49 pesos el kilo) y actualmente se importa de Argentina, China y Estados Unidos (Salinas et al., s.f.; Financiera Rural, 2010; Arteaga, 2012). Por su parte, el 75\% de la producción de leche de cabra se aglutina en La Comarca Lagunera (Coahuila y Durango) y Celaya (Guanajuato) (Améndola et al., 2006).

Los problemas de comercialización de estos productos son los siguientes: mercado inestable, ausencia total of 9'004,377 heads, half of which (50\%) are in five states: Puebla (14.9\%), Oaxaca (13.4\%), Guerrero (7.5\%), Coahuila (7.3 \%) and San Luis Potosí $(6.8 \%)$ (Table 1). The goats have adapted to the arid or semi-arid regions of these states thanks to their ability to survive in situations of scarcity and the extensive management that flocks are given (Nagel et al., 2006; Escareño et al., 2012).

The number of sheep and goats in México is low, in comparison to other places of the world. Data from FAO (in Pérez et al., s.f.:3) indicate that the sheep world population in 1999 was 1,083 million heads, distributed in Asia (38.3\%), Africa (19.7\%), Oceania (15.8 \%), Europe (15\%), South America (9.7 \%), and North and Central America (1.5\%). For goats, Escareño et al. (2012) state that there are 617 million, with higher proportions in Asia (66\%) and Africa $(27.4 \%)$, and lower in Europe $(3.5 \%)$ and America (3\%).

\section{PrinCiPAl PRODUCTS: MEAT, SHEEP WOOL AND GOAT MILK}

México is the $17^{\text {th }}$ meat producer in the world (Escareño et al., 2012). However, in the ruminant sector, beef concentrates approximately $95 \%$ of the market value. The consumption of sheep meat was $1 \%$ of the total in 2011, with 1.0 kilograms of consumption per capita, compared to 16.5 kilograms of beef. By 2005, the amount had only increased to 1.3 kilograms annually per person, and in 2011 its consumption was $0.95 \%$ ) (Pérez, s.f.; Morales et al., 2004; Améndola et al., 2006; Arteaga, 2012). With goat meat, something similar occurs, since it represents $0.85 \%$ of the national market (Gómez and Echavarría, 2006).

Other products obtained from small ruminants are sheep wool and goat milk. The first has a presence in four states with artisanal textile tradition (Hidalgo, Estado de México, Zacatecas and Tlaxcala), but it is in decline because of the increase in synthetic fiber use. In 2008, 4518 tons of wool were produced, with a fall of $31 \%$ compared to 1980 . In 2011 , the production remained virtually the same (4696 tons). Wool has a quite low profitable price (3.49 pesos per kilo) and is currently imported from Argentina, China and the United States (Salinas et al., s.f.; Financiera Rural, 2010; Arteaga, 2012). In turn, $75 \%$ of the goat milk production is concentrated in 
de precios de garantía (Hernández, 2000); intermediarismo (Gómez y Echavarría, 2006); bajos niveles de producción y uso de tecnología (Pérez et al., s.f.); bajo rendimiento y margen de ganancias (Salinas et al., s.f.; Gómez et al., 2012). Para evitar el intermediarismo se propone la agregación de valor y la creación de microempresas (por ejemplo de queso de cabra) que, sin embargo, también suelen enfrentar problemas de mercadeo.

\section{Los tres tipos de sistemas productivos}

Un sistema productivo es un conjunto de elementos técnicos y humanos relacionados entre sí, que presenta distintos arreglos en uso de insumos, formas de manejo y relaciones de trabajo. La producción de pequeños rumiantes generalmente opera bajo una de tres modalidades: intensivo, semi-intensivo o mixto y extensivo. En el primero, los animales se encuentran confinados en instalaciones tecnificadas (corrales, pesebres, comederos, bebederos). Se utilizan razas de alto rendimiento, insumos industriales y sistemas de sanidad, manejo de desechos, programas de nutrición y reproducción. El sistema mixto combina la agricultura con la crianza de animales, los cuales generalmente se alimentan de pastizales inducidos o cultivados, pastos ubicados en las orillas de caminos, esquilmos agrícolas, granos básicos (por ejemplo, trozos de mazorca o granos de maíz), alimentos elaborados por sus dueño/as y concentrados industriales en cantidades limitadas. Los animales son concebidos como un complemento a la nutrición familiar y la economía doméstica. Por último, en el sistema extensivo los animales se pastorean durante el día y se guardan en la noche (Toledo 2003; Améndola et al. 2006; Martínez-González et al., 2013).

El sistema mixto es el predominante para el caso de los ovinos mexicanos. Vieyra et al. (2009:249) señalan que en $66 \%$ de las unidades de producción ovina del país, los animales se utilizan tanto para la venta como para el autoconsumo. La proporción para el estado de Veracruz es similar (63\%) (Pérez et al., s.f.). En el Estado de México, $73 \%$ de las unidades de producción son mixtas (Martínez-González et al., 2011). Para los caprinos, Tovar (2009) señala que 400000 familias (millón y medio de personas) tienen como actividad principal o complementaria, la cría de cabras bajo el esquema de una ganadería extensiva que se practica en las regiones áridas y semiáridas del país (Hernández, 2000). En Guerrero, el
La Comarca Lagunera (Coahuila and Durango) and Celaya (Guanajuato) (Améndola et al., 2006).

The problems with commercialization of these products are the following: unstable market, absence of guarantee prices (Hernández, 2000); presence of intermediaries (Gómez and Echavarría, 2006); low levels of production and use of technology (Pérez et al., s.f.); low yield and profit margin (Salinas et al., s.f.; Gómez et al., 2012). To avoid the use of intermediaries, the aggregation of value and the creation of microenterprises (for example, for goat's cheese), are proposed, although they also tend to face market problems.

\section{The three types of productive systems}

A productive system is a set of technical and human elements related to each other, which present different arrangements in the use of inputs, forms of management and work relationships. The production of small ruminants generally operates under one of three modalities: intensive, semi-intensive or mixed and extensive. In the first, animals are confined in technified facilities (pens, mangers, troughs, drinking troughs). High-yielding breeds and industrial inputs are used, as well as sanitation systems, waste management, and nutrition and reproduction programs. The mixed system combines agriculture with animal breeding; animals are generally fed from induced or cultivated pastures, grasses located on the sides of the roads, agricultural residues, basic grains (for example, pieces of corncobs or maize grains), feed made by the owners, and industrial concentrates in limited amounts. The animals are conceived as a complement to family nutrition and domestic economy. Lastly, in the extensive system animals are grazed during the day and kept at night (Toledo 2003; Améndola et al. 2006; Martínez-González et al., 2013).

The mixed system is the predominant one for the case of Mexican sheep. Vieyra et al. (2009:249) point out that in $66 \%$ of the sheep production units, the animals are used both for sales and for auto-consumption. The proportion for the state of Veracruz is similar (63\%) (Pérez et al., s.f.). In Estado de México, $73 \%$ of the production units are mixed (Martínez-González et al., 2011). For the goats, Tovar (2009) points out that 400000 families (one million and a half people) have the principal 
sistema mixto es el predominante $(68 \%)$ debido a la baja disponibilidad y mala calidad de las áreas forrajeras para los hatos caprinos (Martínez-González et al., 2013).

De acuerdo a Parsons et al. (2011), dos tercios de la población rural más pobre combinan la agricultura con la ganadería a pequeña escala, por lo que los sistemas productivos encontrados en México son comunes en otras partes del mundo. Esta predominancia se explica por tres razones principales. Primero, el pastoreo semi-intensivo y extensivo es quizás la mejor, si no es que la única manera de utilizar zonas áridas e infértiles (Eade y Williams, 1995). Segundo, el ganado menor tiene múltiples funciones: es utilizado para fiestas y ceremonias y favorece la circulación de nutrientes (por ejemplo con el uso de estiércol como abono), por lo que es complementario a la agricultura (Okaly y Sumberg, 1995; FAO, 2012). Tercero y último, el sistema mixto es bastante eficiente en la generación de ingresos dentro de un esquema diversificado. Cuando Martínez-González (2011:371) señalan que $78 \%$ de las unidades de producción del Estado de México "conciben a la ovinocultura como una actividad de ahorro o complementaria", están apuntando hacia las estrategias que los y las campesinas utilizan para protegerse de gastos imprevistos. Parsons et al. (2011) indican que el sistema mixto provee de mayores ingresos que el intensivo debido a que utiliza recursos locales.

\section{RELACIONES DE TRABAJO EN LA GANADERÍA MENOR: UN ANÁLISIS DE GÉNERO}

En la caracterización de los sistemas productivos hay un tema central: el papel del trabajo. Entre más intensivo sea el sistema, se requerirá de menos mano de obra debido a la tecnificación del proceso productivo y viceversa. En otras palabras, se distingue entre el modo de producción intensivo, que ahorra en fuerza de trabajo, y el extensivo o mixto, que sí la utiliza en abundancia (Escareño et al., 2011). Esta sección analiza, bajo el enfoque de género, el papel del trabajo en la ganadería menor practicada en México.

\section{El productor}

Algunos trabajos refieren que el cuidado animal está a cargo del "productor", que se asume de sexo masculino, de facto jefe de familia y principal proveedor. El or complementary activity of breeding goats under the scheme of extensive livestock production that is practiced in arid and semi-arid regions of the country (Hernández, 2000). In Guerrero, the mixed system predominates $(68 \%)$ due to the low availability and bad quality of the fodder areas for goat herds (Martínez-González et al., 2013).

According to Parsons et al. (2011), two thirds of the poorest rural population combines agriculture with small-scale livestock production, which is why the productive systems found in México are common in other parts of the world. This predominance is explained by three main reasons. First, semi-intensive and extensive grazing is probably the best, if not the only way of using arid and infertile zones (Eade and Williams, 1995). Second, minor livestock has multiple functions: it is used for festivities and ceremonies and favors the circulation of nutrients (for example, with the use of manure as fertilizer), so it is complementary to agriculture (Okaly and Sumberg, 1995; FAO, 2012). Third and last, the mixed system is rather efficient in the generation of income within a diversified scheme. When Martínez-González (2011:371) points out that $78 \%$ of the production units in Estado de México, "conceive sheep breeding as an activity for savings or complementary", they are pointing to the strategies that peasants use to protect themselves from unforeseen expenses. Parsons et al. (2011) indicate that the mixed system provides higher income than the intensive one because it uses local resources.

\section{WORK RELATIONSHIPS IN MINOR STOCKBREEDING: A GENDER ANALYSIS}

In the characterization of productive systems there is a central theme: the role of labor. As the system is more intensive, it will require less work due to the technification of the productive process, and vice versa. In other words, in the intensive production system, it is clear that it saves in labor, while the extensive or mixed one uses it in abundance (Escareño et al., 2011). This section analyzes the role of work in minor stockbreeding practiced in México, with a gender approach.

\section{The producer}

Some studies describe that animal care is in charge of the "producer", who is assumed to be 
productor se encarga de labores agrícolas, la generación de ingresos y la crianza de animales. Esta visión conduce a afirmaciones como la siguiente: "dentro de las desventajas de los productores de subsistencia se encuentra el contar con poco tiempo para dedicar al cuidado de ovinos, ya que se emplean en otras actividades para adquirir ingresos, principalmente como obreros" (Pérez et al., s.f.:27). Esta frase asume que nadie más puede encargarse de los hatos. Los productores son considerados dueños de los animales, tomadores de todas las decisiones relacionadas con ellos y, por lo tanto, beneficiarios naturales de servicios financieros, técnicos y veterinarios. No se investigan las distintas responsabilidades de género que hacen posible que las familias campesinas sobrevivan diversificando actividades.

\section{Trabajo familiar}

Otros trabajos utilizan el concepto de "trabajo familiar" para referirse a la enorme cantidad de actividades que implica el cuidado de animales. Constituye un mejor acercamiento a la realidad, puesto que reconoce que el productor vive en familia. Por ejemplo, Hernández (2000) señala que la producción caprina de Puebla involucra de seis a diez horas de mano de obra familiar, mientras que Escareño et al. (2011:239) sostienen que "los miembros de la familia representan una fuente de labor importante" entre "pequeńos productores" de la Comarca Lagunera. Gómez et al. (2012) indican que la crianza de los nueve millones de cabras que existen en el país es una "actividad familiar". Sin embargo, estos trabajos no reflexionan sobre las implicaciones de que la mano de obra familiar sea no pagada, lo cual necesariamente tiene que involucrar negociaciones e intercambios al interior de la familia sobre la cantidad de trabajo, el tiempo invertido y los ingresos generados, desde una posición de poder o falta de éste.

Varios autores y autoras suponen que las decisiones relacionadas con los rebaños son tomadas por "la familia" y no por los hombres y las mujeres la conforman. Véanse, por ejemplo, las siguientes afirmaciones: "si la familia puede permitírselo" (Arriaga-Jordán y Pearson, 2004:107) o "una vez que la familia ha ahorrado suficiente" (Arriaga-Jordán et al., 2005a:590; traducción propia), el ganado menor (ovinos, caprinos) se vende o intercambia por especies mayores (bovinos, equinos). La familia es male, de facto head of the household and primary provider. The producer is in charge of agricultural tasks, income generation and animal breeding. This vision leads to statements such as the following: "among the disadvantages of subsistence producers there is having little time to devote to sheep care, since they are busy with other activities to obtain income, primarily as workers" (Pérez et al., s.f.:27). This sentence assumes that nobody else can take care of the herds. The producers are considered owners of the animals, makers of all decisions related to them, and therefore, natural beneficiaries of the financial, technical and veterinary services. The different gender responsibilities, which make it possible for peasant families to survive by diversifying activities, are not studied.

\section{Family work}

Other studies use the concept of "family work" to refer to the huge number of activities that breeding animals implies. It constitutes a better approach to reality, since it recognizes that the producer lives in a family. For example, Hernández (2000) points out that goat production in Puebla involves six to ten hours of family labor, while Escareño et al. (2011:239) mention that "members of the family represent an important source of labor" among "small-scale producers" in La Comarca Lagunera. Gómez et al. (2012) indicate that breeding of the nine million goats in the country is a "family activity". However, these studies do not reflect upon the implications of family labor not being paid, which necessarily has to involve negotiations and exchanges inside the family related to the amount of work, the time invested and the income generated, from a position of power or lack thereof.

Several authors (men and women) assume that the decisions related to the flocks are made by "the family" and not by the men and the women that integrate it. See, for example, the following statements: "if the family can afford it" (Arriaga-Jordán and Pearson, 2004:107) or "once the family has saved enough money" (Arriaga-Jordán et al., 2005a:590), the minor livestock (sheep, goats) is sold or exchanged for larger species (cattle, equine). The family is conceived as an abstract entity, with decision-making power of its own, beyond its members. 
concebida como un ente abstracto, con poder de decisión propio, más allá de sus integrantes.

\section{Mujeres, nińos y ancianos}

Algunos trabajos desglosan la categoría "trabajo familiar", al señalar específicamente qué integrantes de la familia son responsables de la crianza de animales. Arriaga-Jordán et al. (2005b:833; traducción propia) indican que el cuidado de ovinos entre los Mazahuas del Estado de México está a cargo de "mujeres, niños y ancianos", los cuales constituyen una fuerza de trabajo subutilizada, un "recurso de la unidad doméstica... que de otra manera no sería utilizado". Gómez et al. (2012:2) reportan una situación similar ocasionada por la migración masculina en San Luis Potosí. Hernández et al. (2001:238) ofrecen los siguientes porcentajes para la caprinocultura de la mixteca poblana: "el pastoreo lo realiza el mismo productor (44,9 p.100 de casos), su hijo (34,8 p.100), su esposa (3,1 p.100), o personal contratado $(17,1$ p.100)". Tovar (2009:42; traducción propia) reporta que en ciertas regiones del país, "las mujeres juegan un papel fundamental [en la producción caprina], si no es que todo", sin profundizar en esta afirmación.

Este enfoque visibiliza a tres distintos grupos de personas (mujeres, niños, ancianos). Sin embargo, no analiza las diferencias entre ellos. Sigue pendiente adentrarse de manera más decidida en los intercambios al interior de la familia para identificar los factores que hacen que, bajo ciertas circunstancias, trabajen ciertas personas más que otras. Estas circunstancias pueden estar relacionadas con el tipo de animal, de sistema productivo o de ecosistema, y requieren ser analizado usando un enfoque comparativo (Ajala, 1995).

\section{Las pastoras-artesanas de Chiapas}

Los trabajos dedicados a las pastoras tzoztiles de los altos de Chiapas resaltan su contribución al ingreso familiar (al menos $30 \%$ del total) a través de la elaboración y venta de artesanías textiles (Perezgrovas y Castro, 2000; Gómez-Castro et al., 2011). El reconocimiento de los conocimientos y necesidades de las mujeres ha servido para diseñar intervenciones participativas destinadas a la mejora genética de la especie y reducir el índice de mortalidad neonatal (Perezgrovas et al., 1994; Alemán et al., 2002).

\section{Women, children and the elderly}

Some studies break down the category of "family work", by describing specifically which members of the family are responsible for animal breeding. Arriaga-Jordán et al. (2005b:833) indicate that caring for sheep among Mazahuas in Estado de México is in charge of "women, children and the elderly", who constitute an underutilized labor force, a "resource of the domestic unit... that otherwise would not be used". Gómez et al. (2012:2) report a similar situation caused by male migration in San Luis Potosí. Hernández et al. (2001:238) offer the following percentages for goat breeding in Puebla's Mixtec region: "grazing is done by the producer himself (44.9\% of cases), his son (34.8\%), his wife (3.1\%), or hired staff (17.1\%)". Tovar (2009:42) reports that in certain regions of the country, "women play a fundamental role [in goat production], if not all of it", without delving into this statement.

This approach makes visible three different groups of people (women, children, and the elderly). However, it does not analyze the difference between them. Thorough studying in a more decisive manner is still pending, with regard to the exchanges inside the family to identify the factors that make certain people work more than others under certain circumstances. These circumstances could be related to the type of animal, of productive system or ecosystem, and must be analyzed using a comparative approach (Ajala, 1995).

\section{The shepherdesses-artisans of Chiapas}

The studies devoted to Tzotzil shepherdesses in the Chiapas highlands highlight their contribution to the family income (at least $30 \%$ of the total), through the elaboration and sale of textile handcrafts (Perezgrovas and Castro, 2000; Gómez-Castro et al., 2011). The recognition of women's knowledge and needs has served to design participative interventions destined to improving the species genetics and reducing the index of neonatal mortality (Perezgrovas et al., 1994; Alemán et al., 2002).

In these studies, the viewpoint is focused not only in the animal herd, but rather in the complete cycle of the productive cycle, including the sale of certain products (handcrafts) and the interactions with other elements, for example agriculture (through the use 
En estos trabajos la mirada se concentra no sólo en el hato animal, sino en el ciclo completo del proceso productivo, incluyendo la venta de ciertos productos (artesanías) y las interacciones con otros elementos, por ejemplo la agricultura (a través del uso de abono y rastrojos). Sin embargo, estos trabajos son más la excepción que la norma y es necesario fomentarlos. Hay que añadirles, además, un enfoque de género que sea capaz de analizar la división genérica del trabajo, las diferencias de género en el acceso a recursos y beneficios, y el distinto poder de decisión entre hombres y mujeres. Es decir, además de reconocer el trabajo femenino, hay que escudriñar cómo se construye la relación entre trabajo, poder y acceso diferenciado a recursos y beneficios.

\section{Alternativas TeÓrico-Metodológicas PARA EL ESTUDIO DEL GANADO MENOR CON ENFOQUE DE GÉNERO}

El enfoque de género es producto de la segunda ola del feminismo que surgió en los años sesenta del siglo pasado. Ha sido utilizado para analizar la construcción simbólica del mundo social a partir de la diferencia sexual. Este análisis ha hecho posible documentar la existencia de un sistema educativo y un mercado laboral segregado por género, la doble o triple jornada laboral de las mujeres, distintas formas de violencia de género, la escasa participación femenina en espacios formales de la política, entre otras muchas contribuciones.

El concepto de género se refiere al conjunto de roles, rasgos de personalidad, actitudes, comportamientos y valores socialmente construidos y asignados a cada sexo. Mientras que el sexo biológico está determinado por características anatómicas, el género es aprendido a través de la socialización y, por lo tanto, puede variar en el tiempo y en el espacio de una cultura a otra. El género es una categoría relacional que no se refiere únicamente a las mujeres o a los hombres, sino a las relaciones entre ambos. En este sentido, el análisis de género es la estrategia utilizada para estudiar el impacto diferenciado de leyes, políticas y programas en mujeres y hombres. Como tal, supone la obtención de información desagregada por sexo para entender las distintas oportunidades, formas de participación y beneficios que mujeres y hombres derivan de determinadas iniciativas (UNEG, 2014).

En el campo de los sistemas agropecuarios, el trabajo pionero de Boserup (2007), publicado por primera of manure and stubble). However, these studies are more the exception than the norm and it is necessary to foster them. In addition, a gender approach capable of analyzing gender division of labor should be added, as well as gender differences in the access to resources and benefits, and the different power of decision between men and women. That is, in addition to acknowledging feminine work, the relation between work, power and the differentiated access to resources and benefits should be scrutinized.

\section{THEORETICAL-METHODOLOGICAL ALTERNATIVES TO THE STUDY OF MINOR LIVESTOCK WITH A GENDER APPROACH}

The gender approach is a product of the second wave of feminism that arose in the 1970s. It has been used to analyze the symbolic construction of the social world stemming from sexual difference. This analysis has made possible documenting the existence of an educational system and a labor market segregated by gender, the double or triple workday of women, different forms of gender violence, the scarce feminine participation in formal spaces of politics, among many other contributions.

The concept of gender refers to the set of roles, personality traits, attitudes, behaviors and socially-constructed values assigned to each sex. While biological sex is determined by anatomical characteristics, gender is learned through socialization and, therefore, could vary in time and space from one culture to another. Gender is a relational category that does not refer solely to women or men, but rather to the relationships between both. In this sense, gender analysis is the strategy used to study the differentiated impact of laws, policies and programs on men and women. As such, it entails obtaining information disaggregated by sex to understand the different opportunities, forms of participation and benefits that women and men derive from specific initiatives (UNEG, 2014).

In the field of agricultural and livestock systems, the pioneering work by Boserup (2007), published for the first time in 1970, made clear that modernization has a differentiated impact on men and women, in detriment of the latter in terms of policies of agrarian reform, technological transference and credit services. Women have received much less land than men, and they have been excluded from 
vez en 1970, dejó claro que la modernización tiene un impacto diferenciado en hombres y mujeres, en detrimento de estas últimas en lo que se refiere a las políticas de reforma agraria, transferencia tecnológica y servicios crediticios. Las mujeres han recibido mucho menos tierra que los hombres, han sido excluidas de innovaciones tecnológicas y del acceso a créditos. Esta es una realidad que todavía se constata en la mayoría de los países del mundo, a pesar de que fue detectada hace ya varias décadas (World Bank, 2009).

Distintas autoras han desarrollado conceptos que ayudan a explicar la persistencia de estas desigualdades. La corriente Género, Medio Ambiente y Desarrollo (GMAD) incorpora la mirada de género a la discusión sobre la sustentabilidad, al analizar la división genérica del trabajo y el papel de distintas instituciones en recrear la inequidad en el manejo de recursos naturales dentro de ecosistemas específicos (Rico, 1997; López-Castellano, 2013). Las estrategias propuestas para reducir dicha inequidad son el empoderamiento femenino y la transversalización de la perspectiva de género en las leyes, políticas y programas de todas las áreas del desarrollo y niveles de gobierno, con la finalidad de que mujeres y hombres disfruten de los mismos derechos y oportunidades (Inter-Agency Standing Committee, 2006; Holvoet \& Inberg, 2012).

La corriente de GMAD puede hacer notables contribuciones al estudio de la ganadería menor en México. Permite redefinir algunos conceptos básicos, por ejemplo, "sistema productivo" que, como su nombre lo dice, se refiere primordialmente al trabajo del "productor", asumiendo que realiza sus actividades de manera aislada y que su trabajo es el más importante porque implica la transformación de bienes, la provisión de servicios y la generación de valor. Esta visión impide considerar al trabajo reproductivo, es decir, el tiempo dedicado a la crianza de hijos e hijas, al cuidado de otras personas y a labores domésticas, que comúnmente están a cargo de las mujeres. El trabajo reproductivo no ha sido reconocido como tal y no es tomado en cuenta en el análisis científico y la formulación de políticas. Incorporarlo al análisis permite diferenciar por género la disponibilidad de tiempo y los conocimientos específicos sobre determinados procesos y ámbitos de acción. Considerar tanto el trabajo productivo como el reproductivo, además, permite tomar en cuenta cuestiones básicas de justicia de género, por ejemplo, la doble jornada technological innovation and access to credit. This is a reality that is still seen in most countries of the world, although it was detected several decades ago (World Bank, 2009).

Different women authors have developed concepts that help explain the persistence of these inequalities. The trend of Gender, Environment and Development (Género, Medio Ambiente y Desarrollo, GMAD) incorporates the viewpoint of gender to the discussion about sustainability, when analyzing the labor gender division and the role of different institutions in recreating inequality in the management of natural resources within specific ecosystems (Rico, 1997; López-Castellano, 2013). The strategies proposed to reduce this inequality are feminine empowerment and transversalization of the gender perspective in laws, policies and programs of all the development areas and levels of government, with the aim of women and men enjoying the same rights and opportunities (Inter-Agency Standing Committee, 2006; Holvoet \& Inberg, 2012).

The GMAD trend could make notable contributions to the study of minor livestock in México. It allows redefining some basic concepts, for example, "productive system", which as its name implies, refers fundamentally to the work of the "producer", assuming he performs his activities in an isolated manner and that his work is the most important because it implies the transformation of goods, the production of services, and the generation of value. This vision impedes considering reproductive work, that is, the time devoted to raising children, taking care of other people, and domestic labors, which are commonly women's responsibility. Reproductive work has not been recognized as such and is not taken into account in the scientific analysis and the formulation of policies. Incorporating it into the analysis allows differentiating by gender the availability of time and the specific knowledge about certain processes and scopes of action. Considering both productive work and reproductive work also allows taking into account basic issues of gender justice, for example, the double workday of women, thus avoiding for animal breeding programs to reproduce it or increase it (Leach et al., 1999).

Another concept that must be reformulated for a better analysis is that of family, whose definition under a patriarchal view includes the man who provides and the woman who takes care, where the 
de las mujeres, evitando así que los programas de cuidado animal la reproduzcan o incrementen (Leach $e t$ al., 1999).

Otro concepto que debe ser reformulado para un mejor análisis es el de familia, cuya definición bajo la mirada patriarcal incluye al hombre proveedor y a la mujer cuidadora, donde el primero es quien aporta recursos monetarios y toma las decisiones económicas (inversiones, adquisiciones) mientras que la segunda realiza labores domésticas y provee de atenciones físicas, psicológicas y afectivas a hijos e hijas. Se supone que ambos roles son complementarios y se viven en harmonía. Trasladar esta visión al estudio de la producción campesina implica considerar a las mujeres como incapaces de generar recursos monetarios, tomar decisiones y realizar ciertas actividades (Kabeer, 1995). En el caso del ganado menor, significa desconocer su manejo de hatos y contribución a la economía doméstica. Esta visión limita mucho el tipo de participación que ellas pueden tener en determinado programa.

Amartya Sen (1987) propone transitar del modelo de harmonía familiar a uno donde se reconozca "el conflicto cooperativo". Este nuevo modelo demanda visualizar diferencias de poder por género, edad, parentesco, entre los y las integrantes de una familia, además de una visión no unitaria donde siempre cabe la posibilidad de cooperar por el bien común, pero también de entrar en conflicto en torno al uso, acceso y control sobre recursos materiales y simbólicos. Esta propuesta permite entender de manera más fehaciente la distribución del trabajo entre distintas personas, los patrones de propiedad de los animales, el proceso de toma de decisiones en torno a la adopción de nuevas tecnologías, las estrategias familiares de mercadeo de determinados productos, las limitantes que impone la falta de acceso a tierras de pastoreo, agua, cultivos, forraje, por mencionar sólo algunos aspectos importantes para la crianza animal.

En pocas palabras, la familia es una entre muchas instituciones que determina el acceso de hombres y mujeres a recursos que pueden ser críticos para la sobrevivencia. Cada integrante tiene distinto poder para decidir, negociar y actuar, producto de las asimetrías de género. En muchas culturas, los hombres gozan del privilegio de imponer medidas en los demás (Kabeer, 1995). Este hecho no puede pasar desapercibido para los y las promotoras de tecnologías de crianza animal cuando lo que se quiere hacer es first is the one who contributes monetary resources and makes economic decisions (investments, acquisitions), while the latter performs domestic work and provides physical, psychological and affective attention to sons and daughters. It is assumed that both roles are complementary and experienced in harmony. Transporting this vision to the study of peasant production implies considering women as incapable of generating monetary resources, making decisions and performing certain activities (Kabeer, 1995). In the case of minor livestock, it means ignoring her handling of herds and contribution to domestic economy. This viewpoint much limits the type of participation that women can have in a specific program.

Amartya Sen (1987) suggests moving from the model of family harmony to one where the "cooperative conflict" is acknowledged. This new model demands visualizing differences of power per gender, age, kinship, between members of a family, in addition to a non-unitary vision where there is always the possibility of cooperating for the common good, but also of entering into conflict around the use, access and control of material and symbolic resources. This proposal allows understanding in a more reliable manner the distribution of labor between different people, the patterns of animal property, the process of decision-making around the adoption of new technologies, the family strategies for marketing certain products, and the limitations that the lack of access to lands for grazing, water, cultivation and fodder imposes, among other important aspects for animal breeding.

In sum, family is one among many institutions that determine the access of men and women to resources that can be critical for survival. Each member has different power to decide, negotiate and act, product of gender asymmetries. In many cultures men have the privilege of imposing measures on others (Kabeer, 1995). This fact cannot be ignored by promoters of technologies for animal breeding, when what is attempted is precisely to increase the possibilities of success of their interventions.

Animal science and public policy destined to the sector have great challenges ahead. It is important to design field tools that are sensitive to gender (workshops and interviews with women and men, questionnaires that ask about the tasks of all members of the family). In the phase of information collection, 
precisamente incrementar las posibilidades de éxito de sus intervenciones.

La ciencia animal y la política pública destinada al sector tienen grandes retos por delante. Es importante diseñar herramientas de campo sensibles al género (talleres y entrevistas con mujeres y hombres, cuestionarios que pregunten por las labores de todos los integrantes de la familia). En la fase de recolección de información, no es recomendable dirigirse únicamente al "jefe de familia", asumiendo que él lo sabe todo con relación a los animales. Sólo así se podrán tener datos como los de Merkel et al. (2009:145), que identificó una "proporción mayor de mujeres que de hombres que se caracterizan a sí mismas como productoras de tiempo completo" en la industria caprina de Estados Unidos. La generación de datos desagregados por sexo es fundamental para conocer las actividades de mujeres y hombres en los sistemas productivos del país y diseñar políticas y programas acordes a las necesidades de los y las beneficiarias.

Desde un punto de vista conceptual es recomendable abandonar los términos "productor" y "trabajo familiar" para explorar la división genérica del trabajo que opera en cada sistema productivo, es decir, distinguir exactamente qué actividades realizan mujeres y hombres de distintas edades, por qué, y cómo varían de un contexto a otro. Hay que trascender la mera descripción de actividades (quién hace qué), ya que cada actividad está cargada de valor y otorga poder a quien las realiza (Kabeer, 1995). En México y otros lugares de Latinoamérica, algunos estudios utilizan el término de "amas de casa" para referirse a las mujeres del campo, y se piensa que sus labores constituyen una "ayuda" para el jefe de familia (Deere y León, 2003). Es necesario trascender estos términos para comenzar a identificar patrones de participación laboral por género en las distintas modalidades de la ganadería menor mexicana. ¿Qué actividades realizan mujeres y hombres de distintas edades en los sistemas productivos ovino y caprino en México, bajo qué circunstancias y por qué? ¿Cómo influyen los ecosistemas, el tamaño de los hatos, las actividades de otros integrantes de la unidad de producción? ¿Cómo podemos relacionar todos estos elementos en modelos analíticos que visibilicen el trabajo y los aportes de mujeres y hombres de distintas edades en cada uno de los tres sistemas productivos de ganado menor?

También es necesario comparar los aportes monetarios obtenidos de animales en relación con otros: it is not advisable to address only the "head of the household", assuming he knows everything with regard to the animals. Only thus could there be data like those by Merkel et al. (2009:145), who identified a "larger proportion of women than men who describe themselves as full-time producers" in the goat industry in the United States. The generation of data disaggregated by sex is fundamental to explore the activities of women and men in the productive systems of the country and to design policies and programs according to the needs of the beneficiaries (men and women).

From a conceptual point of view, it is advisable to abandon the terms "producer" and "family labor", in order to explore the gender division of work that operates in each productive system; that is, to distinguish exactly which activities are performed by women and men of different ages, why and how they vary from one context to another. The mere description of activities (who does what) should be transcended, since each activity is charged with value and grants power to whoever performs it (Kabeer, 1995). In México and other places in Latin America, some studies use the term "housewives" to refer to women in the countryside, and it is thought that their work constitutes "help" for the head of the household (Deere and León, 2003). It is necessary to transcend these terms to begin to identify patterns of labor participation by gender in the different modalities of the Mexican minor livestock. What activities do women and men of different ages perform in the sheep and goat productive systems in México, under what circumstances and why? How do ecosystems, the size of herds, and the activities of other members of the production unit influence this? How can we relate all these elements in analytical models that make visible the work and contributions by men and women of different ages in each one of the three productive systems for minor livestock?

It is also necessary to compare the monetary contributions obtained from animals in relation to others: agriculture, sale of products of non-animal origin, remittances, paid work. A finer analysis even calls for exploring the relationship between net profits and patterns of use of income by men and women. The exchanges and negotiations inside the family around the responsibilities and workloads, the power relations in decision-making and the distribution of benefits, the gender differences in access and control 
agricultura, venta de productos de origen no animal, remesas, trabajo asalariado. Un análisis más fino llama incluso a explorar la relación entre ganancias netas y patrones en el uso de los ingresos por parte de hombres y mujeres. Los intercambios y negociaciones al interior de la familia en torno a responsabilidades y cargas de trabajo, las relaciones de poder en la toma de decisiones y la distribución de los beneficios, las diferencias de género en el acceso y control sobre insumos (agua, tierra, crédito, servicios veterinarios) son fundamentales para entender la dinámica del sistema productivo desde la perspectiva de género.

Al momento de hacer el análisis, las unidades de producción deben ubicarse dentro del contexto más amplio de la liberación comercial, el retiro de apoyos para la agricultura familiar y diversificada, la creciente demanda de carne de res, la expansión de la ganadería intensiva, la monopolización de los mercados, el proceso de arrebato de tierras y la pérdida de recursos genéticos (Eade y Williams 1995; Sinn et al. 1999; World Bank 2009; FAO 2012; Califano y Echazú s.f.). De acuerdo a la FAO (en LEISA editorial, 2002:6), un tercio de los 4,000 razas de animales domésticos está en peligro de extinción. Las unidades productivas responden a estos retos haciendo cambios en los usos del suelo o priorizando ciertas actividades por encima de otras, lo cual tiene consecuencias diferenciadas por género y edad.

En el caso de México, no está de más añadir a este panorama los siguientes elementos contextuales: la migración y violencia en el campo; los proyectos de generación de energía, mineros y eólicos; las sequías e inundaciones ocasionadas por el calentamiento global; la pérdida de biodiversidad (pastos y hierbas silvestres). Cada uno tendrá impactos diferenciados en el trabajo que mujeres y hombres realizan en relación con los animales. Por ejemplo, el acceso a los recursos naturales y humanos puede verse reducido, así como la capacidad de tomar decisiones. Las cargas de trabajo y los derechos de propiedad variarán con cambios en la tenencia de la tierra. El estado nutricional de mujeres, niñas y niños puede verse afectado a medida que se produce para el mercado más que para la autosubsistencia. Si las mujeres se distancian o abandonan por completo la producción animal, se ponen en riesgo invaluables recursos genéticos y conocimientos tradicionales relacionados con ellos, además de la seguridad alimentaria de sus hogares. of inputs (water, land, credit, veterinary services) are fundamental for understanding the dynamics of the productive system from the gender perspective.

At the moment of performing the analysis, the production units must be placed within a broader context of market liberation, withdrawal of supports for family and diversified agriculture, growing demand for beef, expansion of intensive stockbreeding, monopolization of markets, process of land snatching and loss of genetic resources (Eade and Williams 1995; Sinn et al. 1999; World Bank 2009; FAO 2012; Califano and Echazú s.f.). According to FAO (in LEISA editorial, 2002:6), a third of the 4,000 breeds of domestic animals is in danger of extinction. Productive units respond to these challenges by making changes in the land uses or by prioritizing certain activities over others, which has consequences differentiated by gender and age.

In the case of México, it is worthwhile to add to this scenario the following contextual elements: migration and violence in the countryside; projects for energy generation, mining and wind farming; droughts and flooding caused by global warming; loss of biodiversity (grasses and wild weeds). Each one will have differentiated impacts on the work that women and men perform in relation to animals. For example, access to natural and human resources can be reduced, as well as the capacity to make decisions. The workloads and rights to property will vary with changes in land ownership. The nutritional state of women, girls and boys can be affected as production is directed more at the market than to self-subsistence. If women distance themselves or completely abandon animal production, invaluable genetic resources and traditional knowledge related to this are placed at risk, in addition to the food security in their households.

\section{ConClusions}

Sheep and goats are marginal in México, compared to their presence in other parts of the world. With regard to beef, their consumption is also reduced. However, both species are an important part of the Mexican rural and culinary tradition. The size of the sheep herd in México has increased in recent years, compared to the goats'. Currently, the main sheep product is meat, since wool is in decadence due to the growing use of synthetic materials. In the case 


\section{Conclusiones}

Ovinos y caprinos son marginales en México, en comparación con su presencia en otras partes del mundo. En relación con la carne de res, su consumo también es reducido. Sin embargo, ambas especies son parte importante de la tradición rural y culinaria mexicana. El tamaño del hato ovino de México ha aumentado en los últimos años, en comparación con el caprino. Actualmente, el principal producto de los ovinos es la carne, ya que la lana se encuentra en decadencia debido al creciente uso de materias sintéticas. En el caso de los caprinos, es más importante la producción de leche que la de carne, pero se concentra sólo en dos regiones del país (Comarca Lagunera y Celaya, Guanajuato).

La producción de pequeños rumiantes ha sido clasificada en tres tipos: intensiva, semi-intensiva o mixta y extensiva. La primera se refiere a animales confinados con alto uso de la tecnología; es una minoría en ambas especies. En la segunda, la producción animal se combina con la agricultura, por lo que los animales aportan nutrientes a los cultivos de los cuales frecuentemente se alimentan. La tercera y última se refiere al pastoreo como actividad principal. El tema de las relaciones de trabajo es central a la discusión, porque se asume que a menor mano de obra, mayor será el grado de tecnificación y viceversa.

Se encontraron cuatro formas de analizar las relaciones de trabajo en estos sistemas productivos. En la primera, se asume que el productor (en masculino) es el encargado de mantener a toda la familia, realizar y decidir sobre todas las actividades, incluyendo la producción animal. La segunda ya reconoce que éstos viven en familia y utiliza el término trabajo familiar, sin distinguir ni explicar quién trabaja y por qué. En la tercera, el término de familia va adquiriendo rostro: se trata de mujeres, niños y ancianos, sin distinguir aportes entre ellos. El cuarto enfoque es más integral porque abarca no sólo el cuidado animal, sino también el procesamiento de sus derivados, lo cual visibiliza el trabajo de las mujeres. Sin embargo, este último enfoque tendría que incorporar elementos clave de la teoría de género para aumentar la complejidad de su análisis, entre ellos la división genérica del trabajo, las diferencias de género en el acceso a recursos y beneficios, y el distinto poder de decisión de hombres y mujeres.

El artículo ofrece nuevas rutas teórico-metodológicas para analizar los sistemas productivos de ganado of goats, milk production is more important than meat, but it is concentrated only in two regions of the country (Comarca Lagunera and Celaya, Guanajuato).

The production of small ruminants has been classified into three types: intensive, semi-intensive or mixed and extensive. The first refers to confined animals with a high use of technology; it is a minority in both species. In the second, animal production is combined with agriculture, so that animals contribute nutrients to the crops from which they frequently feed. The third and last one refers to grazing as the main activity. The theme of work relations is central to the discussion, because it is assumed that if there is less labor, the degree of technification will be higher, and vice versa.

Four ways of analyzing work relations in these productive systems were found. In the first, it is assumed that the producer (male) is the one in charge of supporting the whole family, performing and deciding about all activities, including animal production. The second already recognizes that they live within a family and uses the term of family work, without distinguishing or explaining who works and why. In the third, the term starts to acquire a face: it is women, children and the elderly, without distinguishing contributions by them. The fourth approach is more comprehensive because it covers not only animal care, but also processing of its byproducts, which makes women's work visible. However, this last approach would have to incorporate key elements from gender theory to increase the complexity of its analysis, among them gender division of labor, gender differences in access to resources and benefits, and the different power of decision between men and women.

The article offers new theoretical-methodological routes to analyze the minor livestock productive systems in a more effective manner. The GMAD trend allows redefining some basic concepts, for example, productive system, family, and work, which in turn leads to methodological strategies that make the participation of women and men of different ages visible, in the three productive systems identified in the country, and in the various stages that each one involves. It also allows analyzing animal production with regard to all the strategies for diversification performed by the different members of a family.

These new definitions allow us to reformulate basic questions that we felt were already answered: 
menor de manera más efectiva. La corriente GMAD permite redefinir algunos conceptos básicos, por ejemplo, sistema productivo, familia, trabajo, lo cual conduce a su vez a estrategias metodológicas que visibilizan la participación de mujeres y hombres de distintas edades en los tres sistemas productivos identificados en el país, y en las diversas etapas que involucra cada uno. También permite analizar la producción animal en relación con todas las estrategias de diversificación realizadas por los distintos integrantes de la familia.

Estas nuevas definiciones nos permiten reformular preguntas básicas que ya creíamos contestadas: ¿para qué tiene animales la gente? ¿Cuántos? ¿Cuáles prefieren ellos y ellas? ¿Por qué? ¿De quiénes son realmente? ¿De quién es la tierra, el agua, el forraje con el que se les alimenta? ¿Qué hacen con el dinero que ganan cuando venden uno? ¿De qué otras actividades obtienen recursos económicos para sobrevivir? La respuesta a estas preguntas, enmarcadas siempre dentro del contexto más amplio de globalización y liberalización de mercados, permitirá superar los términos que invisibilizan la división genérica del trabajo, la dinámica de acceso a los recursos y la distribución de beneficios por género en la producción animal.

En conclusión, los y las científicas especializadas en producción animal, y los y las diseñadoras de programas, deben partir del hecho de que las relaciones de género son muy importantes para el mantenimiento o mejoramiento de cualquier sistema productivo. Estas relaciones deben ser analizadas en iniciativas de investigación y tomadas en cuenta en programas de intervención con el fin de incrementar la equidad en la distribución del trabajo y de los beneficios entre la población atendida.

\section{Literatura Citada}

Ajala, A.A. 1995. Women's tasks in the management of goats in Southern Nigeria. Small Ruminant Research Núm. 15. pp: 203-208.

Alemán Santillán, Trinidad, Juan López Méndez, Ángel Martínez Vázquez, y Lorenzo Hernández López. 2002. Retos de un sistema productivo indígena: Altos de Chiapas. Revista LEISA junio. pp: 12-13.

Améndola, Ricardo, Epigmenio Castillo, y Pedro Martínez. 2006. Country pasture and forage resource profiles: México. Rome, Italy, FAO.

Arriaga-Jordán, C.M. A.M. Pedraza-Fuentes, L.G. VelázquezBeltrán, E.G. Nava-Bernal, y M.C. Chávez Mejía. 2005a. Economic contribution of draught Animals to Mazahua smallholder campesino farming systems in the highlands of
Why do people have animals? How many? Which do they (men and women) prefer? Why? Whose are they, really? Who owns the land, water, fodder, with which they are fed? What do they do with the money that they earn when they sell one? From what other activities do they obtain economic resources to survive? The answer to these questions, always framed by the broader context of globalization and market liberalization, will allow overcoming the terms that make invisible the gender division of labor, the dynamics of access to resources, and the distribution of benefits by gender in animal production.

In conclusion, scientists (women and men) specialized in animal production, and program designers, should start from the fact that gender relations are very important for the maintenance or improvement of any productive system. These relationships should be analyzed in research initiatives and taken into account in intervention programs with the aim of increasing equity in labor distribution and the benefits among the population being addressed.

- End of the English version -

Central Mexico. Tropical Animal Health and Production 37. pp: 589-597.

Arriaga-Jordán, C.M. A. M. Pedraza-Fuentes, E. G. Nava-Bernal, M. C. Chávez-Mejía, and O. A. Castelán-Ortega. 2005b. Livestock agrodiversity of Mazahua smallholder campesino systems in the highlands of central Mexico. Human Ecology. Vol. 33, Núm. 6. pp: 821-845.

Arriaga-Jordán, C.M. y R.A. Pearson. 2004. The contribution of livestock to smallholder livelihoods: the situation in Mexico. In: E. Owen, T. Smith, M. A. Steele, S. Anderson, A. J. Duncan y M. Herrero (eds), Responding to the livestock revolution: the role of globalization and implications for poverty alleviation. Nottingham, United Kingdom, Nottingham University. pp: 99-115.

Arteaga Castelán, Juan de Dios. 2012. La ovinocultura en México. Realidad, retos y oportunidades. Segundo Foro de Ovinos de Pelo. Veracruz, 18 y 19 de octubre de 2012.

Boserup, Esther. 2007. Women's role in economic development. Virginia, EUA, Earth Scan.

Budak, D.B., N. Darcan, and M. Kantar. 2005. Women farmers and extension services in small ruminant production in mountain areas of Turkey. Journal of Arid Environments Núm. 62. pp: 507-515.

Califano, Laura María, y Fernando Echazu. s.f. La diversidad de los sistemas ganaderos campesinos de la Puna Jujeńa. Determinación en el marco de un proyecto de extensión. Argentina, INTA EEA Abra Pampa.

Deere, Carmen Diana, y Magdalena León de Leal. 2003. The gender asset gap: land in Latin America. World Develop- 
ment Vol. 31, Núm. 6. pp: 925-047.

Eade, Deborah, and Suzanne Williams. 1995. The OXFAM handbook of development and relief. London, OXFAM.

Escareño, Luis Manuel, Homero Salinas-González, Maria Wurzinger, Luis Iñiguez, Johann Sölkner, y Cesar Meza-Herrera. 2012. Dairy goat production systems. Status quo, perspectives and challenges. Tropical Animal Health Production Vol. 45, Núm. 1. pp: 17-34.

Escareño Sánchez, Luis Manuel, María Wurzinger, Francisco Pastor López, Homero Salinas, Johann Sölkner, y Luis Ińiguez. 2011. La cabra y los sistemas de producción caprina de los pequeños productores de la Comarca Lagunera. Revista Chapingo, Serie Forestales y del Ambiente Núm. 17. pp: 235-246.

FAO. 2012. Invisible Guardians. Women manage livestock diversity. Rome, Italy, FAO.

Financiera Rural. 2010. Monografía lana. Dirección General Adjunta de Planeación Estratégica y Análisis Sectorial, Dirección Ejecutiva de Análisis Sectorial, México, Financiera Rural.

Flintan, Fiona. 2008. Estudio sobre buenas prácticas. El empoderamiento de las mujeres en sociedades pastoriles. Addis Abeba, Etiopía, PNUD, UICN.

Gómez-Castro, H., J., Nahed-Toral, Q. López-Tirado, T. Alemán-Santillán, M. Parra-Vázquez, S. Cortina-Villar, R. Pinto-Ruiz, y F. Guevara-Hernández. 2011. Holistic conceptualization of the sheep production system of the Chiapas highlands. Research Journal of the Biological Sciences Vol. 6, Núm. 7. pp: 314-321.

Gómez-Ruiz, Walter, Juan M. Pinos-Rodríguez, Juan R. AguirreRivera, and Juan C. García-López. 2012. Analysis of a goat milk cheese industry in a desert rangeland of Mexico. Pastoralism: Research, Policy and Practice Vol. 2, Núm. 5. pp: 2-11.

Gómez Ruiz, Walter, y Francisco Echavarría Chaires. 2006. Los mercados asociados con los sistemas de producción de caprinos y las oportunidades de mercado. En http://evirtual. uaslp.mx/Ambiental/Pmpca/Biblioteca/Articulos/PMPCA Gome_Ruiz_\%202006.pdf [Acceso el día primero de agosto de 2013].

Hernández, J.S., E. Rodero, M. Herrera, J.V. Delgado, C. Barba, y A. Sierra. 2001. La caprinocultura en la Mixteca Poblana (México). Descripción e identificación de factores limitantes. Archivos Zootecnia Núm. 50. pp: 231-239.

Hernández, J.S. 2000. La caprinocultura en el marco de la ganadería poblana (México): contribución de la especie caprina y sistemas de producción. Archivos Zootecnia Núm. 49. pp: 341-352.

Holvoet, Nathalie y Liesbeth Inberg. 2012. Changing aid policies through a gender lens: An international perspective and the case of the Dutch development cooperation. Journal of International Women's Studies Vol. 13, Núm. 3. pp: 1-16.

Inter-Agency Standing Committee. 2006. Women, Girls, Boys and Men: Different Needs - Equal Opportunities. Gender Handbook in Humanitarian Action. En http://www.humanitarianinfo.org/iasc/gender [Acceso el día 20 de mayo de 2015].

Kabeer, Naila. 1995. Reversed realities. Gender hierarchies in development thought. Verso, London, United Kingdom.

Leach, Melissa, Robin Mearns, y Ian Scoones. 1999. Environmental entitlements: dynamics and institutions in commu- nity-based natural resource management. World Development Vol. 17, Núm. 2. pp: 225-247.

LEISA editorial. 2002. Crianza animal. ¿Industrial o integrada a la agricultura? Revista LEISA junio. pp: 5-6.

López-Castellano, Fernando. 2013. Medio ambiente y desarrollo. Miradas feministas desde ambos hemisferios. Universidad de Granada, Granada, España.

Martínez-González, Enrique, Manrrubio Muñoz-Rodríguez, Vinicio Santoyo-Cortés, Dolores Gómez-Pérez, y Reyes Altamirano-Cárdenas. 2013. Lecciones de la promoción de proyectos caprinos a través del Programa Estratégico de Seguridad Alimentaria en Guerrero, México. Agricultura, Sociedad y Desarrollo Vol. 10, Núm. 2. pp: 177-193.

Martínez-González, Enrique, Manrrubio Muńoz-Rodríguez, José Guadalupe García-Muñiz, Vinicio Horacio SantoyoCortés, Reyes Altamirano-Cárdenas, y Constantino Romero-Márquez. 2011. El fomento de la ovinocultura familiar en México mediante subsidios en activos: lecciones aprendidas. Agronomía Mesoamericana. Vol. 22, Núm. 2. pp: 367-377.

Merkel, Roger, Terry Gipson, Tilahun Sahlun. 2009. Gender differences in an online certification program for goat producers. Tropical and subtropical agroecosystems Vol. 11, Núm. 1. pp: 145-149.

Morales, Mario, Juan Pablo Martínez Dávila, Glafiro Torres Hernández, y José Evaristo Pacheco Velasco. 2004. Evaluación del potencial para la producción ovina con el enfoque de agroecosistemas en un ejido de Veracruz, México. Técnicas Pecuarias de México Vol. 42, Núm. 3. pp: 347-359.

Nagel P., M. Wurzinger, L. Ińiguez, F. Echavarría Chairez, M. de J. Flores Nájera, J. M. Pinos Rodríguez, W. J. Gómez Ruiz, and W. Zollitsch. 2006. Characterization of two goat production systems in the Highlands of Mexico. International Research on Food Security. Natural Resource Management and Rural Development, Bonn, October 11-13, 2006.

Nahed-Toral, José. 2002. Animales domésticos y agroecosistemas campesinos. Revista LEISA junio. pp: 10-11.

Okaly, C., y Sumberg J.E. 1995. Sheep and goats, men and women. Agricultural Systems Núm. 18. pp: 39-59.

Parsons, David, Charles F. Nicholson, Robert W. Blake, Quirine M. Ketterings, Luis Ramírez-Aviles, Jerome H. Cherney, y Danny G. Fox. 2011. Application of a simulation model for assessing integration of smallholder shifting cultivation and sheep production in Yucatán, Mexico. Agricultural Systems Núm. 104. pp: 13-19.

Peacock, Christie. 2005. Goats - A pathway out of poverty. Small Ruminant Research Núm. 60. pp: 179-186.

Perezgrovas Garza, Raúl e Hilda Castro Gámez. 2000. El borrego Chiapas y el sistema tradicional de manejo de ovinos entre las pastoras tzotziles. Archivos de Zootecnia Núm. 49. pp: 391-403.

Perezgrovas, Raúl, Marisela Peralta y Pastor Pedraza. 1994. Sheep husbandry among Tzotzil Indians: who learns from whom? RRA Notes Núm. 20. pp: 20-70.

Pérez Hernández, Ponciano, Armando Arrieta González, Bernardino Candelaria Martínez, Omar Arroniz Sánchez, Silvia López Ortiz, Héctor Chalate Molina, Pablo Díaz Rivera, y Concepción del Carmen Ahuja Aguirre. s.f. Caracterización del sistema producto ovino en el estado de Veracruz. México, Colegio de Postgraduados y Fundación PRODUCE Veracruz. 
Pollott, Geoff, and R. Trevor Wilson. 2009. Sheep and goats for diverse products and profits. Rome, Italy, FAO.

Rico, María Nieves. 1997. Género, medio ambiente y sustentabilidad del desarrollo. Ponencia presentada en la Séptima Conferencia Regional sobre la Integración de la Mujer en el Desarrollo Económico y Social de América Latina y el Caribe, Santiago de Chile, 19-21 de noviembre de 1997.

SAGARPA. 2011. Servicio de Información agroalimentaria y pesquera. http://www.campomexicano.gob.mx/portal_siap/ Integracion/EstadisticaBasica/Pecuario/PoblacionGanadera/ ProductoEspecie/ovino.pdf. [Acceso el 20 de enero de 2013].

Salinas González, Homero, Francisco Echavarría Chaires, Manuel J. Flores Nájera, Miguel A. Flores Ortiz, Ramón Gutiérrez Luna, y Agustín F. Rumayor Rodriguez. s.f. Tecnología en sistemas de producción caprinos en el semi-desierto de Zacatecas. http://biblioteca.inifap.gob.mx:8080/xmlui/ bitstream/handle/123456789/1939/Tecnologia\%20en $\% 20$ sistemas $\% 20 \mathrm{de} \% 20$ produccion $\% 20$ caprinos $\% 20$ en $\% 20$ el\%20simidesierto $\% 20 \mathrm{de} \% 20$ zacatecas.pdf? sequence $=1$ [Acceso el primero de agosto de 2013].

Sen, Amartya. 1987. Gender and cooperative conflicts. Helsinki, Finland, World Institute for Development Economics Research.

Sinn, R., J. Ketzis, and T. Chen. 1999. The role of woman in the sheep and goat sector. Small Ruminant Research Núm. 34. pp: 259-269.
Taj, Sajida, Arshed Bashir, Rizwana Shahid, y Hasnain Shah. 2012. Livestock development through micro-credit. A hope for poor resource women in rural areas of Faisalabad, Punjab. Journal of Agricultural Research, Vol. 50, Núm. 1. pp: 135-143.

Todd, Helen. 1998. Women climbing out of poverty through credit; or what do cows have to do with it? Livestock Research for Rural Development. Vol. 10, Núm. 3. pp: 1-7.

Toledo, Víctor. 2003. Ecología, espiritualidad y conocimiento. México, PNUMA y Universidad Iberoamericana.

Tovar Luna, Ignacio. 2009. Goat production in Mexico. Overview of the industry and its production practices. Proceedings of the 24th Annual Goat Field Day. Oklahoma, Langston University.

Vieyra, J., J.P. Muñoz, E. Manrique, and J.C.R. Santos. 2009. Assessment of sheep farming systems within San Salvador District (State of Hidalgo). Options Méditerranéennes Núm. 91. pp: 249-252.

UNEG (United Nations Evaluation Group). 2014. Integrating human rights and gender equality in evaluation. New York.

World Bank. 2009. Gender in Agriculture Source Book. Washington D.C., World Bank. 